\title{
Impact of Training and Development on the Performance of Employees - A Comparative Study on Select Banks in Sultanate of Oman
}

\author{
Shouvik Sanyal ${ }^{\mathrm{a}^{*}}$, Mohammed Wamique Hisam ${ }^{\text {b }}$ \\ Corresponding Author: ${ }^{a^{*}}$ Assistant Professor, Department of Management and Marketing, College of \\ Commerce and Business Administration, Dhofar University, Salalah, PO Box. 2509, PC.211, Sultanate of \\ Oman. E- mail: shouviksanyal2000@gmail.com \\ ${ }^{\mathrm{b}}$ Assistant Professor, Department of Management and Marketing, College of Commerce and Business \\ Administration, Dhofar University, Salalah, PO Box. 2509, PC.211, Sultanate of Oman.
}

\section{Abstract}

This paper studies the impact of Training and Development practices on the employee performance in the select Omani Public and Private sector banking organizations. The aim of the paper is to analyze the impact of training and development practices on employee performance. The study adopts descriptive research design and it imbibes both primary and secondary data. Convenience sampling method is applied for collecting the data through administering a structured questionnaire. The sample size for the study is 300 . Statistical tools like Pearson Correlation Analysis, Regression Analysis and ANOVA were applied to test the proposed alternate hypothesis. The study concludes that Training and Development Practices have a positive influence on employee performance in the Omani Banking Industry.

\section{Keywords: Training and Development, Employee Performance, Impact.}

\section{Introduction}

Human resources (Armstrong, 2009) have played a significant role in the economic development in most developed countries. Developing countries like India, can adopt these lessons to their growing economy. To manage an organization both large and small requires staffing them with competent personnel. The formal educational system does not adequately teach specific job skills for a position in a particular organization. Few employees have the requisite skills, knowledge,

abilities and competencies needed to work effectively. As a result, many require extensive training to acquire the necessary aforementioned requisites to be able to make substantive contribution towards the organization's growth.

Training is imparting a specific skill to do a particular job while development deals with general enhancement and growth of individual skill and abilities through conscious and unconscious learning. The main purpose of training and development is by improving the employee competencies so that organizations can maximize efficiency and effectiveness of their human

assets. Armstrong (2009) clearly stated in his book that organizations could benefit from training and development through winning the "heart and minds of" their employees to get them to identify with the organization, to exert themselves more on

its behalf and to remain with the organization. If employees are to experience flexibility and effectiveness on the job, they

need to acquire and develop knowledge and skills, and if they are to believe that they are valued by the organization they work for, then they need to see visible signs of management's commitment to their training and career needs. Training and 
development are the processes of investing in people so that they are equipped to perform well. These processes are part of an overall human resource management approach that hopefully will result in people being motivated to perform. It goes without saying therefore that the training and development of employees are an issue that has to be faced by every organization. However, the amount, quality and quantity of training carried out vary enormously from organization to organization. According to Cole (2002), factors influencing the quantity and quality of training and development activities include: the degree of change in the external environment, the degree of internal change, the availability of suitable skills within the existing work-force and the extent to which management see training as a motivating factor in work.

Many organizations meet their needs for training in an ad hoc and haphazard way. Training in these organizations is more or less unplanned and unsystematic. Other organizations however set about identifying their training needs, then design and implement training activities in a rational manner, and finally assess results of training. Employees training plays an important role as it enhances efficiency of an organization and helps employees to boost their performance in an efficient manner. There are many reasons that create the barriers to perform the task such as organization culture and politics. Some of the employees have lack of skills, abilities, knowledge and competencies due to this they are failed to accomplish task on timely basis.

Now days several trainings are obtainable to employees inside the organization, in order to increase their productivity and decrease the frustration. Most of the time the less capable employees prefer to leave the job because they have lack of ability to understand the technicalities of the given task. However, workforce is anticipated to learning new stuff and shows their

commitment level with positive involvement in organizational success. Skilled employees can handle the critical situation in a well-organized manner. Training defined as an "efficient process of getting knowledge, abilities, skills and the behavior to meet the requirements of the job". Training helps employees to meet their existing job requirements or helps employees to increase their productivity. Although, its benefits may spread throughout an employee's career and help employees to meet

their future responsibilities.

Organizations that don't provide training to their employees fail to compete in the market. It generally happens because the employees of such organizations are incapable of enhancing their productivity. In other words, training helps employees to adopt the market chances and make them capable to meet the technology changes and competition. Training has important role in the achievement of organizational goal by integrating the interest of organization and the workforce. An employee is the assets and most important resource for organizations so that organization who provides training to their employees increases their productivity. The training and development is an important function for the survival of any organization.

\section{Scope of the Study}

The outcomes of this research will help and support the banks to identify the Training and Development factors that influence the employee performance in the banking organizations. On the other hand, the research will be helpful in the department of human resource of every organizations which are trying to increase the productivity of their employees.

\section{Review of Literature}

Training is very important for employee's performance in acquiring competencies and help organization to retain its

employees through satisfaction and motivation. Globally day by day the world is modernizing and moving rapidly which is creating many challenges for the organizations. Training can overcome and make an employee's capabilities more efficient

which also contributes in the efficiency of the company. Zohair Abbas (2014) highlighted training as an essential element to an employee for the development of the companies because some of the employees have lack of knowledge skills and 
competencies and failed to accomplish task on timely basis. The sample has been taken from both males and female employees of National Bank of Pakistan. The research is descriptive study and it's quantitative in nature. Primary data was

collected and although secondary data also used to classify the work done. Study provides an empirical evidence of factors that effects employees training and performance of organization.

Mumanthi (2014) highlighted training as there are number of performance concerns about the Kenya police that have arisen due to lack of taking action, failing to prevent and detect crimes, and police forces citizens pay bribe to get their constitutional rights. The sample size was three hundred and eight four police officers. Study was done in Nairobi Kenya and the time period was 2014. Coefficient Reliability was used to justify the findings. From the findings it was indicated that organization should carry out the training needs assessment to determine level of performance. He further concludes that proper monitoring and evaluation influenced the performance of police in Kenya. According to Frankin Dang Kum (2014) ineffectiveness of training and development of employees in the organization reduces the organizational productivity. Data was collected through random sampling method. Research is limited for the employees of ESCON and the population size was concise 60 out of 87 employees. He concludes that the companies who invest on human resource management view training as an opportunity for increasing their long term productivity.

Asma Mehmood (2012) argue that training influence on organization commitment and retention towards the performance of employee. The data was collected from 100 employees of the service sector at Rawalpindi Islamabad Regression methodology has been used in this research. The regression analysis confirmed that satisfaction and mode for career advancement has direct and useful effect on organizational commitment and increases work efficiency of the employees. The findings conclude that training has strong relationship between retention \& performance and organizational commitment.

Azizullah Ghorbani and Dr. Muhammad Ghaffari Fard (2015) highlighted that customers staffs training is very essential to compete the pressure of challenges which bank industry faces on the daily basis. Random sampling method was used and research was conducted in Tehran, Iran. They suggested that customers training is very beneficial to both managers as well as the employees because it affects the performance of employees and also beneficial in performing non-bank financial activities. Githinji Angela (2014) suggested that the training effects the performance of employee among the international civil servants. A survey research design was used for this study 144 staff of the United Nation supports office for the African mission in Somalia involved in this research the finding showed that in general training enhanced employee engagement on change processes.

Komal Javaid, Naveed Ahmad \& Nadeem Iqbal (2014) highlighted the relationship between training and its impact on employee's performance in telecommunication sector D.G Khan Pakistan. 150 employees were chosen for the data analysis.

Finding showed that the managerial performance is meaningfully resolute through the training instructed to the personnel. They further say that training is a significant predictor of the performance. Cynthia Owusu Boateng (2011) pointed the impact of training on employee performance at SG -SSB. Descriptive quantitative method was used in the research and related articles of the topics. Finding showed that indeed training has a significant impact on employee productivity. Training provide benefits to both the performance employees and the organization through the development of knowledge, skills, competencies, behavior and abilities.

Benedicta Appiah (2010) suggested that training enhances knowledge, skills, attributes and competencies and ultimately worker performance and productivity in organization. Data was collected from 30 employees of HFC bank Ghana. Cross functional study was used to justify the findings. Findings of the study showed that training improves the skills, knowledge, abilities, competencies, behavior and confidence of the employee. Atola Janepher Adongo (2013) suggested that mostly organization neglects the importance of training which leads to high turnovers and also increased the cost to hire new employees and finally slowed down the organizational profitability. 419 employees were chosen for data collection in Telkom orange Kenya. Correlation methodology was used in the study. Findings showed that employees feel motivated by the training offered and indeed many have participated in training programs. 
Mahbuba Sultana (2013) highlighted that effective training increase the productivity of employees. Data was collected from 1414 employees. The study was done in Dhaka. Correlation methodology was used in the research. She concludes that employee is the valuable resource for any organization and the success and failure depends upon the performance and productivity of the employees and this study proves that the training improves the productivity of the employees.

Ahmed Mohamed Mohamud (2014) suggested that training affects the employee performance in public sector organization of Kenya. Data was collected from 100 staffs of Machakos branch. Data analysis was done through descriptive statistic. Findings showed training has a significant impact on employee performance and benefits both the individual employees and the organization at large. Ngugi Martha Nyakeo Nyokabi (2014) pointed that training plays a significant role in the development of competencies of new as well as existing employees for effective performance. Data was collected from 800 employees of geothermal development company in Nairobi. This study shows the relationship between training \& development and employee performance. Findings shows that the training of employees is very important factors of both the organization and the employees because it enhances work performance, motivate employees and build confidence in the employees. The employees should acquire knowledge and skills which will assist them in improving their performance by applying relevant courses based on the organizational objectives.

Tom Jingo Onyango (2012) suggested the influence of training and development on employee performance at Medete Tea Factory, Kenya. Descriptive survey method was used and the data was collected through random sampling method. Findings conclude that if Medete tea factory wants to hire and keep quality employees it is a good policy to invest in training and development. Muhammad Ikhlas Khan (2012) highlighted the impact of training in performance of employee some statistical tools or techniques are applied on data like Person correlation and regression analysis through SPSS software. 100 employees

were taken as a sample size of Habib bank and Federal Urdu university of Islamabad. The findings conclude that training contributes significantly to employee's performance so all the organizations who wants to enhance the capabilities of their

employee performance should focus on training.

Ekta Srivastava \& Dr Nisha Agarwal (2014) highlighted that training is very necessary in this changing environment. Primary data was collected through questionnaire which was filled from various branches of axis bank and secondary data was collected from annual rep orts of syndicate banks and axis banks for the year 2008 to 2013 and from RBI publication. The findings conclude that training in private sector bank is better than public sector banks. In future training should be easy to understand so that it will beneficial for the banks as well as to the employees.

\section{Objectives of Study}

1. To examine the impact of Training and Development practices on the performance of employees in the Omani banking Industry.

2. To suggest certain procedural measures for effective implementation of Training and Development practices in order to enhance the employee performance in the Omani banking Industry.

\section{Hypothesis}

In order to intensify the above objectives, the following alternate hypothesis was framed to test the statistical significance and validity.

Ha1: There exists a strong relationship between Training and Development Practices and employee performance.

\section{Research Methodology}

The present research study adopts descriptive research design and the study involves bank employees at different managerial cadre from four commercial banks involving both public and private sector organizations. The public sector banks include National Bank of Oman (NBO) and Oman Arab Bank and the private sector banks include Bank Muscat and HSBC Bank. The study area is restricted to Muscat and Salalah cities in Oman and three branches from every selected bank were identified. From every banking organization 
75 respondents were selected and thus the four banking organizations project a sample size of 300 . Convenience sampling method was used in the study. Both primary and secondary data were used for the research study. The primary data was collected through questionnaire method. The secondary data involves various published documents. For collecting the data, convenience sampling technique was used. The statistical tools like Pearson Correlation, ANOVA and Regression Analysis were used to test the proposed alternate hypothesis.

\begin{tabular}{|c|l|l|l|}
\hline Sampling Particulars & No. of \\
Type of & Name of the Bank & Branch & Respondents \\
\hline Organization & & Saadah & 30 \\
\hline & NBO & Salalah & 30 \\
\hline & & Muscat & 15 \\
\hline & & Saadah & 30 \\
\hline & $\begin{array}{l}\text { Oman Arab } \\
\text { Bank }\end{array}$ & Salalah & 30 \\
\hline & & Muscat & 15 \\
\hline Privat & & Saadah & 30 \\
\hline & $\begin{array}{l}\text { Bank } \\
\text { Muscat }\end{array}$ & Salalah & 30 \\
\hline & & Muscat & 15 \\
\hline & HSBC & Saadah & 30 \\
\hline & & Salalah & 30 \\
\hline & & Muscat & 15 \\
\hline & & Total & 300 \\
\hline
\end{tabular}

\section{Data Analysis}

Table 1: Pearson Correlation Analysis

\begin{tabular}{|c|c|c|c|}
\hline & & \begin{tabular}{|l} 
Employee \\
Performance
\end{tabular} & $\begin{array}{l}\text { Training \& Development } \\
\text { Practices }\end{array}$ \\
\hline \multirow{3}{*}{$\begin{array}{l}\text { Employee } \\
\text { Performance }\end{array}$} & $\begin{array}{l}\text { Pearson } \\
\text { Correlation } \\
\end{array}$ & 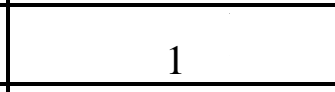 & $0.536 * *$ \\
\hline & $\begin{array}{l}\text { Sig. }(2- \\
\text { tailed) }\end{array}$ & & 0.000 \\
\hline & $\mathrm{N}$ & 300 & 300 \\
\hline \multirow{3}{*}{$\begin{array}{l}\text { Training and } \\
\text { Development } \\
\text { Practices }\end{array}$} & $\begin{array}{l}\text { Pearson } \\
\text { Correlation }\end{array}$ & $0.536 * *$ & \\
\hline & $\begin{array}{l}\text { Sig. (2- } \\
\text { tailed) }\end{array}$ & 0.000 & \\
\hline & $\mathrm{N}$ & 300 & 300 \\
\hline
\end{tabular}

** Significant at 0.01 level

It was found from the above table that the coefficient of correlation between Training and Development practices and employee performance is 0.536 at a significance level of 0.01 (2-tailed). Thus it indicates that there exists a strong linear correlation in between the two identified variables and they are closely related. 
Table 2: Regression Analysis

\begin{tabular}{|c|r|r|c|}
\hline R & R square & Adjusted R square & $\begin{array}{c}\text { Std. Error of the } \\
\text { Estimate }\end{array}$ \\
\hline $0.468^{\mathrm{a}}$ & 0.140 & 0.138 & 3.188 \\
\hline
\end{tabular}

The Regression Analysis shows that there exists a moderate relationship between the Training and Development practices and employee performance. It shows that the Training and Development practices explained $46.8 \%$ of the total variation in employee performance. Thus it indicates that there is a positive relationship in between the two variables.

Table 3: ANOVA Results

\begin{tabular}{|l|c|c|c|c|c|}
\hline & $\begin{array}{c}\text { Sum of } \\
\text { Squares }\end{array}$ & df & Mean Square & F & Sig. \\
\hline Regression & 639.52 & 1 & 639.52 & 36.365 & $0.000^{\circ}$ \\
\hline Residual & 2946.74 & 98 & 18.716 & & \\
\hline Total & 3586.26 & 99 & & & \\
\hline
\end{tabular}

The above table indicates the variance in the model of Training and Development practices with employee performance at $\mathrm{F}$ - value $36.365(\mathrm{p}=0.000)$. It is further tested with regression coefficients for Training and Development practices and employee performance.

Table 4: Coefficient of Regression between Training and Development Practices and Employee Performance

\begin{tabular}{|c|c|c|c|c|c|}
\hline & \multicolumn{2}{|c|}{$\begin{array}{l}\text { Unstandardized } \\
\text { Coefficients }\end{array}$} & \multirow{2}{*}{$\begin{array}{c}\text { Standardize } \\
\text { d } \\
\text { Beta } \\
\text { Coefficients } \\
\end{array}$} & \multirow[t]{2}{*}{$\mathbf{t}$} & \multirow[t]{2}{*}{ Sig. } \\
\hline & $\mathbf{B}$ & Std. err & & & \\
\hline Constant & 12.156 & 1.163 & & 8.938 & \\
\hline $\begin{array}{l}\text { Training and } \\
\text { Development } \\
\text { Practices }\end{array}$ & 0.22 & 0.046 & 0.296 & 4.247 & 0.000 \\
\hline
\end{tabular}

The above table presents coefficient of regression in between training and development practices and employee performance. It shows that regression results at a confidence interval level of $95 \%$ with un standardized data coefficients value of 0.22 indicates a $t-$ value 4.247. (p value of 0.000). Since the calculated value (4.247) is greater than the critical value, alternate hypothesis is accepted. It indicates that Training and Development practices have a strong influence on employee performance in the Indian Banking Industry.

\section{Findings}

1. The study shows that Training and Development programs and Employee performance are interlinked in the select banking industry.

2. The analysis shows that Training and Development programs are strongly influencing the employee performance in the select Banking Industry.

3. It is found from the above study that Training program had certainly increased the performance levels of the select bank employees.

\section{Suggestions}

Need based training programs are to be imparted to the employees by the organizations in order to make them focused on the organizational goals.

$\square$ Equal opportunity for all cadres of employees in the organizations is to be given in order to maintain homogeneous enhancement of skills and techniques. 
Training programs should have their roots in the basic elements like effective Customer Relationship Management, Total Quality Management and Talent Management.

Career Planning and Development Schemes are to be implemented and they should be closely monitored.

\section{Conclusion}

The findings in the research study indicate that there exists a strong correlation between Training and Development practices and Employee Performance in the select banking organizations. This infers that there exists a positive relationship in between Training and Development practices and Employee Performance. Organizations which invest in their employee skills by way of Training and Development activities will certainly reap the profits through employee productivity.

It is very essential on part of the organizations to continuously develop the employee skills in order to maximize employee performance. This is possible only by way of continuous training and development practices. It is a well-known fact that untrained employees could not perform up to the mark and this will certainly affect the overall performance of the organization. As the concept of Training and Development Practices have a significant impact and influence on employee performance and productivity it is essential for the organizations to maintain the ambient environment which involves continuous training process. Organizations which promote training and development practices tend to possess a shining corporate image.

\section{References}

[1] Armstrong, M. (2009) Armstrong's Handbook of Human Resource Management Practice. 11th Edition, Kogan Page Limited, London.

[1] Abbas, Z. (2014). Identification of factors and their impact on employees' training and organizational performance in Pakistan. Kasbit journal of management \& social science, 7(1), 93-109.

[2] Appiah, B. (2012). The impact of training on employee performance: a case study of HFC bank (Ghana) limited.

[3] Adongo, A. J. (2014). Examining the effects of job training on employee performance in mobile telephone industry. A case of Telkom orange Nakuru, Kenya (doctoral dissertation).

[4] Boating, C. O. (2011). Impact assessment of training on employee performance: a case study of SGSSB limited (doctoral dissertation, school of graduate studies, institute of distance learning, Kwame Nkrumah University of science and technology) .

[5] Cole, G.A. (2002) Personnel and Human Resource Management. 5th Edition, York Publishers, Continuum London.

[6] Ghorbani, A., Fard, M. G., \& Buinzahra, I. (2015). The impact of training on employee performance and customer financial and nonfinancial performance of banks (case study: Tejarat bank). Aula Orientalis (issn: 0212-5730), 1, 105-118.

[7] Githinji, A. (2014). Effects of training on employee performance: a case study of United Nations support office for the African union mission in Somalia (doctoral dissertation, United States international university-Africa).

[8] Javaid, K., Ahmad, N., \& Iqbal, N. (2014). Impact of training on employee performance in the context of telecommunication sector of dg khan, (Pakistan). International letters of social and humanistic sciences, (06), 60-73.

[9] Kum, F. D., \& Cowden, R. The impact of training and development on employee performance: a case study of Escon consulting.

[10] Khan, M. I. (2012). The impact of training and motivation on performance of employees. Business review, 7(2), 84-95.

[11] Mumanthi, C. (2014). Effect of training on the performance of national police service. Strategic journal of business \& change management,

[12] Mahmood, A. Impact of training on commitment, retention and performance.

[13] Mohamud, A. M. (2014). The effect of training on employee performance in public sector organizations in Kenya. The case of Chif Machakos County (doctoral dissertation, university of Nairobi). 
[14] Ngugi, M. N. (2014). Perceived relationship between training and development and employee performance in geothermal development company (GDC) (doctoral dissertation, university of Nairobi).

[15] Najeeb, A. Z. (2013). The impact of training and information and communication technology on employee's performance: an empirical study on pharmaceutical manufacturing companies in Amman (doctoral dissertation, Middle East University).

[16] Onyango, T. O. (2012). The influence of training and development on employees ${ }^{\text {ee }}$ performance at Mudete tea factory (doctoral dissertation).

[17] Sultana, M. Impact of training in pharmaceutical industry: an assessment on square pharmaceuticals limited, Bangladesh.

[18] Srivastava, E., \& Agarwal, N. (2014). Impact of training on bank employee performance: a comparative study of public sector bank and private sector bank in India. International journal of advance research in computer science and management studies. 